\title{
Perbedaan Tingkat Stres Pada Ibu Rumah Tangga yang Menggunakan dan Tidak Menggunakan Pembantu Rumah Tangga
}

\author{
Ketut Ariyani Kartika Putri dan Hilda Sudhana \\ Program Studi Psikologi, Fakultas Kedokteran, Universitas Udayana \\ ariyanikartika@gmail.com
}

\begin{abstract}
Abstrak
Pekerjaan rumah tangga adalah pekerjaan non formal yang bersifat kompleks dan tidak mudah dilakukan. Pekerjaan rumah tangga cukup menyita banyak waktu dan tenaga serta dilakukan di dalam rumah setiap hari terutama jika tidak ada yang membantu menyelesaikan pekerjaan tersebut. Hal itu menciptakan kondisi terisolasi dan berpotensi menyebabkan timbulnya stres. Beberapa ibu rumah tangga memilih untuk menggunakan pembantu rumah tangga yang diharapkan dapat membantu menyelesaikan pekerjaan rumah sehari-hari. Penelitian ini ingin melihat perbedaan tingkat stres pada ibu rumah tangga yang menggunakan dan tidak menggunakan pembantu rumah tangga.

Responden dalam penelitian ini berjumlah 180 orang yaitu ibu rumah tangga berusia 30-55 tahun yang tidak bekerja dan berdomisili di daerah Denpasar. Teknik pengambilan sampel dalam penelitian ini yaitu purposive sampling. Skala yang digunakan yaitu skala stres pada ibu rumah tangga. Dari 54 item yang tersedia, 28 item dinyatakan valid dengan nilai reliabilitas 0,901 dan 26 item gugur. Metode analisis data yang digunakan dalam penelitian ini yaitu analisis nonparametrik Two Independent Samples. Hasil dari uji analisis data yaitu terdapat nilai signifikansi $\mathrm{p}=$ 0,000 yang mengindikasikan adanya perbedaan yang signifikan pada kedua kelompok ibu rumah tangga, sehingga kesimpulan dalam penelitian ini adalah ada perbedaan tingkat stres yang signifikan pada ibu rumah tangga yang menggunakan dan tidak menggunakan pembantu. Maka dari itu hipotesis alternatif (Ha) dalam penelitian ini dapat diterima.

Kata kunci : ibu rumah tangga, pembantu rumah tangga, stres.
\end{abstract}

\begin{abstract}
Household chores is a non formal complex task and its not an easy thing to do. To finish the house work needs a lot of time and energy, also most of it must be done in the house every day, especially if no one help to finish it. It creates an isolated condition and may potentially cause stress. Some housewives prefer to hire a housekeeper to help to complete house works daily. This study is aiming to see the difference level of stress between housewives who use and does not use a housekeeper.

Subjects in this research are 180 housewives aged between 30-55 years old who are not working and lives in the Denpasar area. Sampling technique in this study are incidental sampling. The scale used is the scale of the stress on housewives. From the 54 available items, 28 items declared valid with reliability values 0,901 and 26 items fall. Method of analyzing data used in this research is the analysis of non parametric Two Independent Sampel. Results from test data analysis is that there is a significant value of $\mathrm{p}=0.000$ which indicates a significant difference between both group of housewives, so that the conclusions in this research is that there are significant difference levels of stress in housewives who use and does not use a housekeeper. Thus the alternative hypothesis (Ha) in this study is accepted.
\end{abstract}

Keywords : Housewives, housekeeper, stress. 


\section{LATAR BELAKANG}

Pekerjaan rumah tangga adalah jenis pekerjaan non formal yang dilakukan oleh seorang ibu rumah tangga. Menjaga kerapihan dan keteraturan kondisi rumah untuk keluarga merupakan inti utama dari pekerjaan rumah tangga itu sendiri. Begitu kompleksnya kegiatan-kegiatan yang termasuk dalam pekerjaan rumah tangga yang menjadi pekerjaan utama seorang ibu rumah tangga yang tidak bekerja. Mulai dari mengurus anak, memasak, mencuci dan merapikan pakaian seluruh anggota keluarga, sampai perihal mengatur keuangan keluarga. Hal tersebut dianggap sebagai hal yang mudah bagi sebagian orang, tetapi bagi sebagian lagi pekerjaan rumah tangga merupakan hal yang cukup membebani. Jika perihal tentang pekerjaan rumah tangga tidak dilaksanakan atau terlaksana dengan baik, maka hal itu akan mempengaruhi seluruh aspek dalam keluarga itu sendiri baik secara langsung maupun tidak langsung.

Pekerjaan rumah tangga itu sendiri erat kaitannya dengan seorang ibu rumah tangga. Ibu rumah tangga adalah salah satu profesi mulia yang dimiliki oleh perempuan yang sudah berkeluarga. Utamanya bagi seorang ibu rumah tangga yang tidak bekerja, pekerjaan rumah tangga menjadi fokus utama karena sebagian besar waktu yang dihabiskan di dalam rumah. Pekerjaan rumah tangga itu sendiri merupakan pekerjaan yang monoton karena melakukan pekerjaan yang sama setiap hari dan sebagian besar dilakukan di dalam rumah. Keadaan ini dapat memicu terjadinya situasi terisolasi pada ibu rumah tangga dan cenderung mengarah kepada stresor bagi ibu rumah tangga tersebut. Menurut artikel pada salah satu situs berita, dikatakan bahwa seorang pekerja seni di tanah air pernah mengalami stres terkait dengan kesibukannya menjadi seorang ibu rumah tangga tetapi hal itu dapat diatasi dengan baik oleh artis tersebut (Menits Berita, http://news.menits.com/post/2748654930/2013/04/07/.html, akses 14 April 2013). Hal yang sama juga ditulis oleh Panji (http://health.kompas.com/read/2008/08/06/14345736/Bila.Str es.di.Rumah, akses 13 November 2012). bahwa ibu rumah tangga yang bekerja di rumah rentan mengalami stres dalam menghadapi permasalahan rumah tangga jika tidak dihadapi dengan kesiapan mental dan fisik yang baik. Berita yang ditulis pada media mengabarkan bahwa seorang ibu rumah tangga di daerah Magetan, Jawa Timur melakukan bunuh diri karena diduga mengalami stres (Pranoto, http://surabaya.detik.com/read/2013/03/07/121024/2188372/4 75/diduga-stres-ibu-rumah-tangga-loncat-dari-jembatan-

setinggi-50-meter, akses 14 April 2013). Hal ini sangat disayangkan jika melihat dugaan korban mengalami stres dan melakukan tindakan seperti itu. Kondisi stres dapat mempengaruhi keadaan pikiran, perasaan, dan perilaku individu dalam kehidupan sehari-hari. Stres yang dialami oleh seorang ibu rumah tangga terutama yang terkait dengan pekerjaan rumah tangga dapat menyebabkan ibu rumah tangga tersebut merasa tidak nyaman dalam melakukan tugas rumah tangga serta dapat mempengaruhi pikiran, perasaan, maupun perilaku sehari-hari ibu rumah tangga itu sendiri. Oleh sebab itu, perlunya mengatasi stres pada ibu rumah tangga karena stres dapat berisiko mempengaruhi fungsi yang baik individu itu sendiri termasuk fungsi sebagai seorang ibu rumah tangga. Menjadi ibu rumah tangga merupakan profesi yang mulia karena bersifat memberikan pelayanan terbaik bagi seluruh anggota keluarga tanpa diberikan upah. Dwijayanti (1999) dalam jurnalnya menyebutkan bahwa ibu rumah tangga yang tidak bekerja atau singkatnya disebut ibu rumah tangga, memiliki pengertian sebagai wanita yang lebih banyak menghabiskan waktunya dirumah, mempersembahkan waktunya untuk memelihara anak-anak dan mengasuh menurut pola-pola yang diberikan masyarakat. Vuuren (dalam Mumtahinnah, 2002), menyatakan bahwa pekerjaan kaum wanita adalah memasak di rumah, menjahit, berbelanja, menyetrika pakaian dan mengurus anak. Pekerjaan rumah tangga yang begitu kompleks ini tentu tidak mudah dilakukan apalagi jika harus melakukannya seorang diri tanpa bantuan dari orang lain. Hasil penelitian Nurhadi (2009) di Surakarta menyimpulkan bahwa oleh karena pekerjaan dan tugas kerumahtanggaan tidak mempunyai nilai tukar ekonomis, oleh karena itu tugas itu cenderung dianggap rendah. Anggapan bahwa tugas ibu rumah tangga dianggap rendah mampu membuat para wanita yang melaksanakan tugas sebagai ibu rumah tangga menjadi merasa kurang berharga. Menurut Sukmana (1995) tugas ibu rumah tangga dalam kehidupan keluarga yaitu mengatur tata laksana rumah tangga sehingga kondisi keluarga menjadi teratur dan rapih.

Tugas sebagai seorang ibu rumah tangga dapat menjadi kegiatan yang monoton karena sebagian besar dilakukan di dalam rumah. Keadaan tersebut dapat mengarah kepada stres karena disamping menuntut tanggung jawab penuh dalam melaksanakan pekerjaan yang hampir sama setiap hari di lokasi yang sama, juga terisolasi dari dunia luar karena sebagian besar dilakukan di dalam rumah. Hasil penelitian Wulanyani \& Sudiajeng (2006) di Bali menyatakan bahwa pekerjaan rumah tangga merupakan salah satu dari tiga stresor utama pada ibu rumah tangga. Menurut Smet (1994), tuntutan kerja yang terlalu banyak dan beban kerja yang berat dapat menimbulkan stres. Oleh karena itu perlu adanya kekuatan fisik maupun mental untuk bisa melakukan seluruh pekerjaan rumah tangga dengan baik. Sebuah penelitian yang dilakukan oleh National Institute for Child Health and Human Development Study of Early Child Care and Youth Development yang melibatkan 1.300 perempuan menunjukkan bahwa perempuan yang bekerja di luar rumah walau hanya bekerja part time memiliki kesehatan yang lebih baik dan lebih sedikit mengalami gejala depresi dibandingkan dengan perempuan yang mencurahkan waktunya untuk mengurusi rumah dan keluarga (Indriani, 2011). Hal ini disebabkan karena seorang ibu rumah tangga harus terisolasi dari lingkungan di luar rumah ketika melakukan pekerjaan rumah tangganya. Melakukan kegiatan yang monoton yang dilakukan 
di dalam rumah sehari-hari dalam waktu yang berkepanjangan dapat meningkatkan risiko terjadinya stres dan dapat mempengaruhi fungsi yang baik sebagai seorang ibu rumah tangga.

Untuk menghadapi pekerjaan rumah tangga yang begitu bervariasi, ibu rumah tangga sudah memiliki pilihan untuk mengatasinya yaitu dengan menggunakan jasa pembantu rumah tangga. Saat ini sudah banyak biro-biro yang menyediakan jasa pelayanan pembantu rumah tangga. Beberapa ibu rumah tangga yang menginginkan kemudahan dalam mengerjakan pekerjaan rumah tangga lebih memilih untuk menggunakan jasa pembantu rumah tangga (PRT). Hal ini dimaksudkan untuk bisa meringankan tugas dan tanggung jawabnya dalam mengurus pekerjaan rumah tangga seharihari. Pembantu rumah tangga adalah seorang yang dipekerjakan dengan tujuan untuk membantu beberapa pekerjaan rumah tangga yang dengan kata lain meringankan pekerjaan dari keluarga tersebut (Naibaho, 2010). Para ibu rumah tangga bahkan rela mengeluarkan biaya ratusan ribu per bulannya untuk menggaji pembantu rumah tangga demi terlaksananya pekerjaan dalam rumah dengan baik. Saat ini tersedia di kota-kota besar biro yang menyalurkan jasa pembantu rumah tangga yang terlatih karena sudah melalui training sebelumnya, sehingga ketika menghadapi pekerjaan rumah tangga secara nyata, kinerja para pembantu ini dapat memuaskan sang majikan. Hasil penelitian dari Wangi (2008) menyimpulkan bahwa hubungan antara pembantu rumah tangga dengan majikan hanyalah sebatas atasan dan bawahan sehingga pada kenyataannya akan melahirkan hubungan yang sarat dengan perilaku dominasi, diskriminasi, dan eksploitasi sehingga dapat menyebabkan ketidaknyamanan di antara kedua belah pihak atau pada salah satu pihak.

Pada kenyataannya tidak semua pembantu rumah tangga memiliki kinerja yang layak dan memuaskan. Sebagian ibu rumah tangga justru memilih untuk bekerja sendiri dalam melaksanakan tugas dan tanggung jawabnya terhadap pekerjaan rumah tangga. Beberapa ibu merasa bahwa keberadaan pembantu rumah tangga justru merepotkan, ada juga yang merasa keberatan jika harus menggaji pembantu dengan uang ratusan ribu per bulannya, sebagian lagi merasa tidak nyaman jika ada tambahan anggota keluarga dalam rumah mereka. Mereka lebih nyaman jika melakukan kewajiban sebagai ibu rumah tangga sendirian. Mereka nampak lebih menikmati pekerjaan yang dilakukan dan terlihat lebih nyaman dibandingkan dengan ibu rumah tangga lain yang menggunakan jasa pembantu. Kondisi yang tidak nyaman secara berkelanjutan dalam menggunakan pembantu rumah tangga dapat menjadi faktor pemicu stres pada ibu rumah tangga itu sendiri. Beberapa paparan terkait dengan stres pada ibu rumah tangga seperti yang disebutkan di atas, maka melalui penelitian ini peneliti ingin melihat perbedaan tingkat stres baik dari segi kognitif, afektif, perilaku, maupun fisik pada ibu rumah tangga yang menggunakan dan tidak menggunakan jasa pembantu rumah tangga di Denpasar.

\section{METODE}

\section{Variabel dan Definisi Operasional}

Variabel penelitian adalah gejala bervariasi, gejala adalah objek penelitian, jadi variabel adalah objek bervariasi (Arikunto, 1988). Terdapat dua variabel dalam penelitian ini yaitu variabel bebas dan variabel tergantung. Variabel bebas adalah variabel yang berdiri sendiri dan tidak tergantung pada variabel lain (Trisnawati, 2006). Variabel bebas dalam penelitian ini adalah pembantu rumah tangga. Variabel tergantung (dependent variabel) adalah variabel yang dipengaruhi atau yang menjadi akibat karena adanya variabel bebas (Sugiyono, 2012). Variabel tergantung dalam penelitian ini adalah stres.

Definisi operasional dari pembantu rumah tangga yaitu seseorang yang diberi gaji untuk melakukan pekerjaan rumah tangga dalam suatu keluarga dengan tujuan untuk membantu meringankan pekerjaan rumah tangga sehari-hari.

Definisi operasional dari stres yaitu suatu keadaan internal seseorang yang diakibatkan oleh tekanan dan tuntutan baik dari dalam maupun luar diri sehingga dianggap sebagai ancaman terhadap kesejahteraan individu tersebut serta diukur dengan menggunakan skala stres.

\section{Responden}

Populasi adalah seluruh individu yang akan dijadikan sebagai objek penelitian dan keseluruhan individu harus memiliki sifat yang sama (Zaenuri, 2007). Populasi dalam penelitian ini adalah seluruh ibu rumah tangga di Denpasar. Karakteristik sampel yang telah ditetapkan peneliti dalam penelitian ini yaitu ibu rumah tangga yang tidak bekerja berusia 30-55 tahun yang menggunakan dan tidak menggunakan jasa pembantu rumah tangga serta bertempat tinggal di Denpasar. Metode pengambilan sampel yang digunakan dalam penelitian ini purposive sampling, yaitu peneliti mengambil individu sebagai sampel atas dasar tujuan peneliti yang telah disesuaikan dengan karakteristik responden yang diinginkan dalam penelitian ini (Sugiyono, 2005).

\section{Tempat Penelitian}

Responden dalam penelitian ini adalah ibu rumah tangga yang tidak bekerja serta bertempat tinggal di Denpasar. Peneliti memutuskan untuk menggunakan responden di Denpasar karena kemudahan dalam mendapatkan responden yang menggunakan pembantu rumah tangga di perkotaan besar seperti Denpasar. Dalam menentukan jumlah populasi, pada penelitian ini menggunakan rumus penghitungan jumlah 
sampel dari populasi yang tidak diketahui jumlahnya (Higgins, Kleinbaum, \& Miller, 1985), sehingga jumlah sampel minimal yang harus dipenuhi yaitu diperoleh hasil jumlah sampel dalam penelitian ini yaitu 137 siswa. Pada penelitian ini peneliti menetapkan jumlah sampel sebanyak 180 orang.

\section{Alat Ukur}

Skala pengukuran tingkat stres pada ibu rumah tangga disusun untuk mengukur beberapa aspek terkait stres pada ibu rumah tangga yang akan tersebar dalam 54 item. Aspek-aspek yang berada dalam skala stres pada ibu rumah tangga ini yaitu terdiri atas 4 aspek. Aspek yang pertama adalah aspek kognitif. Dalam aspek ini peneliti ingin mengetahui pemahaman seorang ibu rumah tangga terkait kewajiban dan perannya. Selain itu peneliti ingin mengukur intensitas ibu rumah tangga dalam memikirkan berbagai macam pekerjaan rumah sehari-hari yang merupakan kewajibannya. Aspek yang kedua yaitu mengenai afektif. Dalam aspek ini peneliti ingin melihat kecemasan yang dialami seorang ibu rumah tangga dalam menghadapi kewajiban dan perannya melakukan pekerjaan rumah tangga. Kemudian peneliti juga ingin mengetahui perasaan yang dirasakan ketika ibu runah tangga melakukan kewajibannya terkait pekerjaan rumah tangga sehari-hari. Aspek yang ketiga yaitu perilaku. Peneliti ingin melihat agresivitas dari perilaku ibu rumah tangga ketika ia melakukan pekerjaan rumah tangga sehari-hari. Kemudian peneliti juga ingin mengetahui usaha yang dikerahkan dalam melakukan pekerjaan rumah tangga. Selain itu peneliti juga ingin mengetahui intensitas komunikasi responden terkait dengan sosialisasi mereka dengan lingkungan di sekitar. Aspek yang terakhir yaitu aspek fisik. Dalam aspek ini peneliti ingin mengetahui kondisi kesehatan jasmani ibu rumah tangga terkait dengan tingkat stres yang dialami. Selain itu peneliti juga melihat tingkat stres yang dialami dari kualitas tidur dan keberadaan gejala-gejala timbulnya penyakit.

Skala stres pada ibu rumah tangga terdiri dari pernyataan favorable dan unfavorable yang terbagi dalam empat alternatif jawaban, yakni 'sangat tidak setuju', 'tidak setuju', 'setuju', dan 'sangat setuju'.

\section{Metode Pengumpulan Data}

Metode pengumpulan data yang digunakan dalam penelitian ini adalah dengan menggunakan satu kuesioner yaitu untuk mengukur tingkat stres pada ibu rumah tangga. Untuk mengukur variabel bebas yaitu mengetahui responden sedang menggunakan atau tidak menggunakan pembantu rumah tangga, hal ini akan dicantumkan di data demografi yang akan diisi responden sebelum menjawab item kuesioner.
Kuesioner untuk mengukur tingkat stres pada ibu rumah tangga tersedia empat pilihan jawaban, yakni 'sangat tidak setuju', 'tidak setuju', 'setuju', dan 'sangat setuju'. Dalam kuesioner terdapat instruksi mengenai cara menjawab kuesioner, kemudian responden diwajibkan untuk memilih salah satu dari alternatif jawaban dan juga mengisi lembaran identitas data demografi responden.

\section{Teknik Analisis Data}

Validitas adalah ukuran yang menunjukkan tingkattingkat kevalidan atau kesahihan suatu alat (Trisnawati, 2006). Suatu alat ukur yang tinggi validitasnya akan memiliki eror pengukuran yang kecil, artinya skor setiap responden yang diperoleh oleh alat ukur tersebut tidak jauh berbeda dari skor yang sesungguhnya. Penelitian ini menggunakan dua jenis validitas yaitu validitas konstruk dan validitas isi. Validitas konstruk adalah validitas yang menunjukkan sejauhmana suatu tes mengukur trait atau konstruk teoritik yang hendak diukurnya. Validitas isi adalah sejauh mana itemitem dalam tes mencakup keseluruhan kawasan isi yang hendak diukur oleh tes itu (Azwar, 2001). Validitas konstruk didapat dengan menggunakan SPSS for windows versi 17 dengan mencari koefisien korelasi item total pada item. Sebuah butir soal dinyatakan baik atau layak jika memenuhi persyaratan masuk ke dalam interval indeks tertentu (Sugiyono, 2005). Menurut Nugiyantoro (2009) indeks tingkat kesulitan yang dinyatakan baik atau layak adalah berkisar antara 0,20-0,80. Tetapi dalam penelitian ini peneliti menggunakan Tabel Korelasi Product Moment untuk menghitung skor $r$ hitung yang akan dibandingkan dengan $r$ tabel, sesuai taraf signifikan $5 \%$ pada tabel korelasi product moment dengan nilai kritis korefisien korelasi ( $t$ tabel). Suatu item dapat dinyatakan valid apabila nilai $r$ hitung $>r$ tabel, namun sebaliknya apabila nilai $r$ tabel $>r$ hitung, maka item tersebut dinyatakan tidak valid (Nurgiyantoro, Gunawan, \& Marzuki, 2004). Untuk validitas isi peneliti membutuhkan bantuan dari professional judgement untuk mengetahui item-item tersebut dapat mencerminkan aspek yang ingin diujikan. Untuk menguji validitas konstruksi, dapat digunakan pendapat dari ahli (judgement experts). Setelah melewati proses try out, kemudian dilakukan analisa item untuk melihat validitas dan reliabilitas skala. Analisis dilakukan dengan menggunakan bantuan program komputer Statistical Package for Social Science (SPSS) for Windows 17.0.

Reliabilitas menunjukkan sejauh mana hasil pengukuran tetap konsisten bila dilakukan pengukuran dua kali atau lebih terhadap gejala yang sama dan dengan alat pengukur yang sama. Hasil pengukuran dapat dipercaya hasilnya apabila dalam beberapa kali pelaksanaan pengukuran terhadap kelompok responden yang sama diperoleh hasil yang 
relatif sama, selama aspek yang diukur dalam diri responden memang belum berubah (Azwar, 2001). Relatif sama berarti tetap adanya toleransi terhadap perbedaan kecil di antara hasil beberapa kali pengukuran. Tes yang tidak dapat memberikan hasil yang konsisten (reliabel) akan memberikan penafsiran yang keliru mengenai aspek yang diungkapnya (Azwar, 2001). Dalam penelitian ini reliabilitas juga akan ditinjau dengan Cronbach's Alpha dengan bantuan SPSS versi 17.

Analisis data adalah proses penyederhanaan data ke dalam bentuk yang mudah dibaca dan diinterprestasikan (Fitra, 2007). Metode analisis data yang digunakan yaitu Independent Sample T-Test dengan menggunakan SPSS versi 17.0. Independent Sample T-Test digunakan karena dua kelompok sampelnya berasal dari distribusi sampel yang berbeda dan untuk mengetahui apakah perbedaan mean dari dua kelompok tersebut signifikan. Dalam melakukan analisis data, terdapat dua syarat yang harus dipenuhi, yaitu dilakukannya uji asumsi berupa uji normalitas dan uji homogenitas. Uji normalitas merupakan uji yang dilakukan untuk membuktikan data dari sampel yang dimiliki berasal dari yang populasi berdistribusi normal, pengujian dilakukan dengan Kolmogorov-Smirnov. Data dinyatakan berdistribusi normal jika signifikansi lebih besar dari 0,05 atau 5\% (Arikunto, 2006). Uji homogenitas bertujuan untuk mengetahui apakah kedua sampel mempunyai varian yang homogen atau tidak, yaitu dengan membandingkan kedua variansnya menggunakan Levene's test dengan bantuan perangkat lunak SPSS 17.0. Nilai probabilitas lebih besar dari 0,05 maka data berasal dari populasi yang variansnya sama atau homogen (Sugiyono, 2010).

Jika dalam uji parametrik Independent Sample TTest ini menghasilkan data yang tidak memenuhi syarat-syarat untuk dapat menggunakan analisis parametrik, maka peneliti akan menggunakan analisis non parametrik Two Independent Sample.

\section{HASIL PENELITIAN}

Uji coba alat ukur dalam penelitian ini diperlukan untuk dapat mengetahui item-item yang valid atau sahih dan melihat reliabilitas dari item-item tersebut. Sebelum melakukan uji coba alat ukur, terlebih dahulu dilakukan penyebaran kuesioner dalam skala kecil untuk memastikan subjek dapat memahami dengan baik kalimat dalam pernyataan dalam kuesioner tersebut. Hal itu dilakukan dengan memberikan kuesioner kepada 5 orang subjek yang sesuai dengan karakteristik peneliti. Hasilnya menunjukkan bahwa responden cukup memahami dengan baik setiap kalimat dalam pernyataan. Skala tersebut kemudian melalui proses uji coba (try out) untuk dapat menyeleksi item-item yang berkualitas. Skala tersebut diujicobakan kepada 60 orang responden yang tersebar di berbagai tempat.

Data yang telah diperoleh pada saat melakukan uji coba alat ukur penelitian akan dianalisis untuk mengetahui validitas dan reliabilitasnya. Berdasarkan hasil uji coba item yang terdiri dari 35 item kepada 60 orang subyek, Item-item yang valid memiliki indeks korelasi item total yang bergerak antara 0,235 sampai 0,730. Item-item yang digugurkan dalam penelitian ini yaitu item-item yang memiliki indeks korelasi item total $<0,138$ berdasarkan pada nilai kritis koefisien korelasi product moment (Nurgiyantoro, Gunawan, \& Marzuki, 2009). Hasil analisa menggambarkan bahwa dari 54 item yang dibuat tersisa 28 item yang valid dan 26 item lainnya gugur

Koefisien $\alpha$ pada skala stres ini ketika dilakukan seleksi item pada proses try out yaitu 0,901. Hal ini menunjukkan bahwa skala tersebut memiliki reliabilitas yang sangat baik. Sehingga skala tersebut layak dan dapat digunakan untuk penelitian ini. Setelah dilakukan penelitian dengan jumlah responden mencapai 180 orang, koefisien reliabilitas pada skala stres pada ibu rumah tangga yaitu sebesar 0, 929. Angka tersebut menunjukkan bahwa item-item pada skala ini memang layak untuk digunakan dalam penelitian ini.

Syarat yang harus dipenuhi untuk melakukan analisis Independent Sample T-Test diantaranya yaitu data yang didapat melalui penelitian harus melewati uji asumsi berupa uji normalitas dan uji homogenitas. Uji homogenitas digunakan untuk mengetahui apakah variansi-variansi dari sejumlah populasi sama atau tidak. Populasi yang memiliki variasi sama disebut dengan populasi yang homogen (Kusdiyarti, 2007). Homogenitas data dilihat melalui signifikansi $\mathrm{p}$ pada Levene's Test dalam SPPS for windows versi 17.0. hasil dari uji homogenitas menyatakan bahwa varians pada setiap kelompok data memiliki signifikansi dengan (p) sebesar 0,459 yaitu berada di atas signifikansi 0,05. Maka dari itu data penelitian yang memiliki signifikansi sebesar 0,459 ini dapat dinyatakan bahwa varians skor bersifat homogen atau sama.

Penggunaan statistik parametrik mensyaratkan bahwa data setiap variabel yang akan dianalisis harus berdistribusi normal, oleh karena itu harus dilakukan uji normalitas (Sugiyono, 2005). Analisis statistik yang pertama dilakukan dalam rangka analisis data adalah analisis statistik yang berupa uji normalitas sehingga dapat mempertanggungjawabkan langkah-langkah selanjutnya (Nurgiyantoro, 2009). Setelah melihat hasil dari uji normalitas, dapat diketahui bahwa sebaran data memiliki signifikansi (p) 0,000 yaitu berada di bawah 0,05. Melihat pada hasil tersebut, maka dapat dinyatakan bahwa data penelitian ini tidak berdistribusi normal karena signifikansinya berada di bawah 0,05 sehingga dinyatakan sebaran data tidak berdistribusi normal. Oleh karena itu, maka penelitian ini tidak memenuhi salah satu syarat penelitian parametrik yaitu data penelitian harus berdistribusi normal. Statistik parametrik memerlukan terpenuhinya banyak asumsi, dan yang utama 
adalah data yang akan dianalisis harus berdistribusi normal. Sedangkan statistik nonparametris tidak menuntut terpenuhi banyak asumsi, data yang akan dianalisis tidak harus berdistribusi normal atau distribution free (Sugiyono, 2005). Maka dari itu, setelah melalui berbagai pertimbangan, peneliti memutuskan untuk menggunakan analisa statistik non parametrik yaitu Two Independent Sample.

Analisis data dilanjutkan dengan menggunakan metode analisis Two Independent Sample. Analisis data non parametrik ini dilakukan karena alasan yang sudah peneliti ungkapkan sebelumnya yaitu data penelitian yang berdistribusi tidak normal sehingga tidak memenuhi syarat sebagai penelitian parametrik. Oleh karena itu setelah melalui berbagai pertimbangan peneliti mengambil langkah untuk mengubah metode analisis data menjadi non parametrik yaitu Two Independent Samples. Two Independent Samples Test pada hakikatnya sama dengan uji Independent Sample T Test dengan prasyarat yang lebih longgar, meliputi mampu digunakan untuk tipe data ordinal dan tidak memerlukan asumsi terdistribusi normal (Trihendradi, 2005). Ada dua uji popular pada test tersebut yaitu Mann-Whitney dan Kolgomorov-Smirnov. Penelitian ini membandingkan perbedaan variabel tingkat stres pada dua kelompok berbeda yaitu ibu rumah tangga yang menggunakan pembantu dan ibu rumah tangga yang tidak menggunakan pembantu. Analisis dilakukan dengan menggunakan SPSS for windows versi 17.0. Setelah dilakukan analisis, maka hasil yang dapat diketahui yaitu diperoleh nilai signifikansi (p) sebesar 0,000. Angka signifikansi tersebut berada di bawah $0,05(<0,05)$.

$$
\text { Tabel } 1
$$

Hasil Uji Normalitas

\begin{tabular}{l|l}
\hline Kolmogorov-Smimov Z & 2,146
\end{tabular}

Asymp. Sig.(2-tailed) $\quad 0,000$

Berdasarkan pada tabel di atas, dapat diketahui bahwa uji normalitas data dalam penelitian ini menghasilkan signifikansi ( $\mathrm{p}$ ) sebesar $\mathrm{p}=0,000$ atau $\mathrm{p}<0,05$ sehingga data penelitian ini dinyatakan tidak berdistribusi normal.

Tabel 2

Hasil Uji Analisis Data

\begin{tabular}{l|l}
\multicolumn{2}{c}{ Hasil Uji Analisis Data } \\
\hline Uji Homogenitas : & 0,550 \\
Nilai F & 0,459 \\
Signifikansi & 0,000 \\
Two Independent Sample (Sig 2-tailed) & \\
\hline
\end{tabular}

Tabel di atas menggambarkan bahwa ketika dilakukan uji homogenitas data menghasilkan signifikansi (p) sebesar $\mathrm{p}=0,459$ atau $\mathrm{p}>0,05$ sehingga data penelitian ini dinyatakan memiliki varians yang homogen. Saat dilakukan uji hipotesis Two Independent Samples menghasilkan signifikansi ( $p$ ) sebesar $\mathrm{p}=0,000$ sehingga dapat disimpulkan bahwa ada perbedaan tingkat stres yang signifikan pada ibu rumah tangga yang menggunakan dan tidak menggunakan pembantu rumah tangga.
Uji hipotesis dalam penelitian ini dilakukan untuk melihat adanya perbedaan yang muncul atau tidak pada tingkat stres ibu rumah tangga yang menggunakan dan tidak menggunakan pembantu rumah tangga. Untuk melakukan uji hipotesis ini, maka peneliti menggunakan analisis non parametrik Two Independent Sample. Nilai signifikansi yang didapat yaitu sebesar $p=0,000$. Nilai tersebut berada di bawah taraf signifikansi yaitu $\mathrm{p}<0,05$. Berdasarkan hal tersebut maka dapat dinyatakan kesimpulan bahwa terdapat perbedaan terhadap tingkat stres pada ibu rumah tangga baik pada kelompok yang menggunakan pembantu dan tidak menggunakan pembantu. Maka hipotesis alternatif (Ha) penelitian ini yang menyatakan bahwa ada perbedaan tingkat stres pada ibu rumah tangga yang menggunakan dan tidak menggunakan pembantu, dinyatakan dapat diterima. Sedangkan hipotesis nol (H0) dalam penelitian ini yang menyatakan bahwa tidak ada perbedaan tingkat stres pada ibu rumah tangga yang menggunakan dan tidak menggunakan pembantu, dinyatakan ditolak.

Untuk memudahkan dalam memahami tingkatan stres pada responden, maka dalam proses skoring peneliti menggunakan pengkategorian skor yang terbagi dalam 5 kategori yaitu kategori sangat rendah, rendah, sedang, tinggi, dan sangat tinggi. Dalam melakukan kategori skor tersebut, peneliti menggunakan rumus pengkategorian skor dari Azwar (2000).

\begin{tabular}{cccc} 
& \multicolumn{3}{c}{$\begin{array}{c}\text { Tabel 3 } \\
\text { Kategori Skor Skala Stres pada Ibu Rumah Tangga }\end{array}$} \\
\hline Kategori & Skor & $\begin{array}{c}\text { Menggunakan } \\
\text { Pembantu (orang) }\end{array}$ & $\begin{array}{c}\text { Tidak Menggunakan } \\
\text { Pembantu (orang) }\end{array}$ \\
\hline Sangat Rendah & skor $\leq 49$ & 6 & 1 \\
Rendah & $49<$ skor $\leq 63$ & 73 & 12 \\
Sedang & $63<$ skor $\leq 77$ & 11 & 74 \\
Tinggi & $77<$ skor $\leq 91$ & 0 & 3 \\
Sangat Tinggi & $91<$ skor & 0 & 0 \\
\hline
\end{tabular}

Berdasarkan tabel di atas, maka dapat ditarik kesimpulan bahwa kelompok ibu rumah tangga yang menggunakan pembantu rumah tangga memiliki skor stres yang cenderung lebih rendah dibandingkan dengan kelompok ibu rumah tangga yang tidak menggunakan pembantu rumah tangga dalam menyelesaikan pekerjaan rumah sehari-hari..

Peneliti mencoba untuk mengkaji lebih dalam data penelitian ini sebagai data tambahan. dengan melihat perbedaan rentang usia subjek dengan tingkat stres yang dialami. Untuk memudahkan dalam melihat perbedaan, peneliti mengelompokkan usia-usia tersebut ke dalam kategori rentang usia, yaitu kategori rentang usia 30-40 tahun dan 4155 tahun berdasarkan karakteristik rentang usia responden yang telah ditentukan sebelumnya. Analisis tambahan ini dilakukan untuk melihat perbedaan tingkat stres antara kedua kategori rentang usia tersebut. Peneliti menggunakan metode analisis data non parametrik Two Independent Sample. Hasil analisis data menunjukkan bahwa nilai signifikansi yang dihasilkan dengan probabilitas ( $\mathrm{p}$ ) yaitu sebesar $\mathrm{p}=0,069$. 
Nilai signifikansi tersebut berada diatas taraf signifikansi $\mathrm{p}=0,05$. Nilai tersebut menunjukkan bahwa tidak ada perbedaan tingkat stres yang signifikan antara responden pada kategori rentang usia 30-40 tahun dan responden pada kategori rentang usia 41-55 tahun. Hal ini mengindikasikan bahwa tingkat stres pada kelompok usia masa dewasa dini dengan kelompok usia masa dewasa madya tidak memiliki perbedaan yang signifikan.

Data tambahan lainnya dilakukan untuk mengetahui perbedaan tingkat stres pada ibu rumah tangga yang menggunakan dan tidak menggunakan pembantu rumah tangga dilihat dari tiap aspek dalam skala stres pada ibu rumah tangga. Terdapat 4 aspek dalam skala stres pada ibu rumah tangga, yaitu aspek kognitif, afektif, perilaku, dan fisik. Untuk melihat perbedaan tersebut, peneliti menggunakan analisa statistik non parametrik Two Independent Samples. Sebelum dilakukan analisis data, dilakukan pengukuran validitas dan reliabilitas item-item yang terdapat pada tiap-tiap aspek. Nilai validitas tiap item pada setiap aspek memiliki indeks korelasi item total $<0,138$ berdasarkan pada nilai kritis koefisien korelasi product moment.

Selain itu, peneliti juga melakukan uji normalitas dan homogenitas pada data keempat aspek tersebut. Hasilnya yaitu pada keempat aspek tersebut memiliki data yang seluruhnya bersifat tidak normal. Sedangkan pada aspek afektif dan perilaku didapatkan data yang bersifat homogen. Lalu pada aspek kognitif dan aspek fisik memiliki data yang bersifat tidak homogen. Oleh karena data yang dihasilkan bersifat tidak normal secara keseluruhan, maka peneliti menggunakan analisa statistik non parametrik Two Independent Samples.

Tabel 4

Hasil Analisa Two Independent Samples pada Kedua Kelompok Ibu Rumah Tangga Di Tinjau Dari Tiap Aspek dalam Skala Stres Ibu Rumah Tangga

\begin{tabular}{c|c}
\hline Aspek & Nilai Signifikansi \\
\hline Kognitif & 0,000 \\
Afektif & 0,000 \\
Perilaku & 0,000 \\
Fisik & 0,000 \\
\hline
\end{tabular}

Berdasarkan tabel di atas menunjukan bahwa nilai signifikansi pada aspek kognitif, afektif, perilaku dan fisik yaitu $\mathrm{p}=0,000$. Angka tersebut berada di bawah nilai taraf signifikansi 0,05. Hal ini menunjukkan bahwa terdapat perbedaan tingkat stres yang signifikan pada kedua kelompok ibu rumah tangga di tinjau dari aspek kognitif, afektif, perilaku dan fisik. Hal tersebut telah digambarkan juga pada hasil analisis non parametrik Two Independent Samples yang dilakukan pada keempat aspek tersebut dan dapat juga di lihat pada hasil pengkategorian tingkat stres pada masing-masing aspek.

\section{PEMBAHASAN DAN KESIMPULAN}

Hasil penelitian ini yang menyatakan bahwa ada perbedaan tingkat stres pada ibu rumah tangga yang menggunakan dan tidak menggunakan pembantu rumah tangga. Seperti yang telah dijelaskan sebelumnya, dikatakan bahwa wanita memiliki level kronis yang lebih tinggi terkait stresor dalam kehidupan sehari-hari (J. M. Hogan, 2002). Melakukan pekerjaan rumah tangga sebagai seorang ibu rumah tangga adalah sebagai kewajiban seorang wanita yang sudah menikah dan hal tersebut akan menjadi kegiatan dalam kehidupan sehari-harinya. Apabila ibu rumah tangga tersebut tidak bekerja, maka ia akan lebih banyak menghabiskan waktunya dirumah dan melakukan pekerjaan rumah tangga menjadi fokus kegiatan sehari-hari yang harus dilakukan. Ayu dalam jurnalnya pada tahun 2009 menyatakan bahwa wanita tidak dapat secara bebas memilih pekerjaan dan cenderung untuk terisolasi dirumah karena banyaknya pekerjaan yang harus di selesaikan, utamanya bila tidak ada yang membantu mengerjakan pekerjaan rumah tangga. Melakukan pekerjaan rumah tangga yang ada setiap hari cukup menyita waktu bagi para ibu rumah tangga terutama jika tidak menggunakan jasa pembantu rumah tangga dalam membantu menyelesaikannya. Hal tersebut membuat para ibu rumah tangga cenderung lebih banyak menghabiskan waktunya di dalam rumah untuk menyelesaikan pekerjaan rumah sehingga mereka terisolasi di dalam rumah untuk waktu yang cukup lama tergantung dari seberapa cepat mereka dapat menyelesaikan pekerjaan rumah tersebut. Pendapat dari Frieze (1978) mengatakan bahwa isolasi ini cenderung memperkuat perasaan tidak berdaya pada wanita yang pada akhirnya menyebabkan wanita itu lebih mudah mengalami masalah - masalah psikologis. Dwijayanti (1999) menyatakan bahwa ibu rumah tangga yang tidak bekerja lebih banyak menghabiskan waktunya di rumah, mempersembahkan waktunya untuk memelihara anak-anak dan mengasuh menurut pola-pola yang diberikan masyarakat. Penelitian Matud (2004) menyatakan bahwa pada wanita sebagian besar hal yang menyebabkan stres adalah hal mengenai keluarga dan kesehatannya. Pekerjaan rumah tangga yang merupakan kegiatan seorang ibu rumah tangga seharihari juga dapat menjadi faktor pemicu stres sehingga dapat mempengaruhi kemampuan fungsional sebagai seorang ibu rumah tangga.

Pekerjaan seorang ibu rumah tangga begitu beranekaragam. Cakupan kegiatan yang termasuk dalam pekerjaan rumah tangga begitu luas. Kegiatan kecil seperti menjaga kebersihan rumah hingga mengatur keuangan keluarga merupakan bagian dari pekerjaan rumah tangga. Vuuren (dalam Mumtahinnah, 2002) menyatakan bahwa pekerjaan kaum wanita adalah memasak di rumah, menjahit, berbelanja, menyetrika pakaian dan mengurus anak. Sebagai seorang ibu rumah tangga yang baik, seorang wanita tidak hanya memiliki satu peran dalam keluarganya. Menurut Kartono (1992), ibu memiliki peranan sebagai istri, peranan sebagai partner seks, fungsi sebagai ibu dan pendidik, peranan wanita sebagai pengatur rumah tangga, dan peranan sebagai 
partner hidup. Banyaknya peranan yang harus ditanggung oleh seorang ibu rumah tangga, dapat menjadi stresor dari berbagai aspek dalam perannya tersebut. Taylor (1995) dalam bukunya mengatakan bahwa individu yang melakukan terlalu banyak tugas dalam kehidupannya terbukti memiliki tingkat stres yang lebih tinggi. Repetti (dalam Blechman \& Brownell, 1998) mengatakan bahwa kesehatan fisik dan mental pada wanita secara langsung dipengaruhi oleh kebutuhan mereka dalam melakukan coping terhadap peran yang multiple seperti sebagai seorang ibu, pekerja, dan orang tua dari anak-anaknya. Hal tersebut juga bergantung pada kesepakatan yang diberlakukan dalam sebuah keluarga. Apabila dalam sebuah keluarga sudah disepakati bahwa pekerjaan rumah tangga merupakan peran yang ditanggung kedua pasangan suami dan istri, maka beban peran ibu rumah tangga dalam melakukan pekerjaan rumah tangga tidak hanya ditanggung oleh ibu rumah tangga saja tetapi dapat berbagi peran dengan suami. Keputusan pembagian peran seperti itu dapat mempengaruhi beban tugas yang diemban oleh seorang wanita dalam rumah tangga. Pembagian peran dalam mengerjakan pekerjaan rumah tangga bersama suami setidaknya dapat meringankan tugas sebagai seorang ibu dalam sebuah keluarga sehingga dapat menekan timbulnya faktor pemicu stres.

Banyak orang yang menganggap masalah terkait pekerjaan rumah tangga adalah masalah sederhana dan mudah serta tidak menyita banyak waktu, pikiran, maupun tenaga. Namun pada kenyataannya, berdasarkan hasil penelitian ini, ibu rumah tangga yang mengerjakan seluruh pekerjaan rumahnya tanpa dibantu oleh orang lain (dalam hal ini pembantu rumah tangga) memiliki tingkat stres yang lebih tinggi dibandingkan para ibu rumah tangga yang dibantu oleh pembantu rumah tangga. Huber dan Spitze (dalam Sandimin, 2009) mengatakan bahwa pekerjaan yang memiliki dampak secara langsung lebih dihargai dan diberi nilai tinggi oleh masyarakat, sehingga tidak heran jika pekerjaan sebagai ibu rumah tangga memiliki status dan penghargaan ekonomi yang rendah karena dianggap tidak memiliki dampak langsung terhadap perubahan lingkungan sosial dan ekonomi. Pekerjaan rumah tangga tentu tidak dapat memberikan dampak langsung pada perubahan sosial dan ekonomi namun pekerjaan ini lebih mengarah kepada keadaan kesejahteraan sebuah keluarga dalam rumah tangga. Oleh karena itu masih banyak orang yang belum menyadari pentingnya peran seorang ibu rumah tangga dalam menjalankan kewajiban melakukan pekerjaan rumah tangga. Menurut Galbraith (1973) meskipun ibu rumah tangga sudah melakukan beranekaragam pekerjaan rumah tangga, tetapi ibu rumah tangga bukanlah pekerjaan formal yang menghasilkan uang atau gengsi sehingga tidak ada kompensasi finansial yang bisa diberikan. Tentu tidak ada kompensasi finansial yang dapat diberikan karena tugas sebagai seorang ibu rumah tangga merupakan kewajiban yang harus ditanggung ketika seorang wanita memasuki tahapan rumah tangga. Oleh karena itu peran sebagai seorang ibu rumah tangga sangat mulia.

Melakukan pekerjaan rumah tangga yang kompleks dapat menyita sebagian besar waktu dari ibu rumah tangga itu sendiri. Utamanya jika ibu rumah tangga tidak menggunakan jasa pembantu rumah tangga dalam membantu menyelesaikan pekerjaan rumah tangga. Total waktu yang dihabiskan oleh wanita rumah tangga dalam menyelesaikan pekerjaan rumah yang tidak dibayar adalah tinggi, dengan beberapa perkiraan berkisar dari 30 hingga 60 jam per minggu, bila pengasuhan anak dimasukkan (Handoko, 2007). Oleh sebab itu, mengerjakan seluruh pekerjaan rumah tangga seorang diri sebagai kewajiban seorang ibu rumah tangga dan hal tersebut dilakukan setiap hari tentu membutuhkan kesiapan baik secara fisik maupun mental karena sangat berpotensi dalam menyebabkan timbulnya stresor. Faktor pemicu stres tidak hanya berasal dari peristiwa besar, namun dapat juga terjadi dari hal-hal sederhana dalam kehidupan sehari-hari. Stresor sehari-hari menurut Taylor (1995) yaitu seperti terjebak dalam kemacetan lalu lintas, mengantri, melakukan pekerjaan rumah tangga sehari-hari, merupakan hal-hal yang dapat menyebabkan stres. Stres yang dialami oleh seorang ibu rumah tangga dapat mempengaruhi fungsi yang baik pada ibu rumah tangga itu sendiri. Bentuk stres yang dapat dialami terwujud dalam berbagai macam gejala yang dapat dilihat dari gejala fisik, kognitif, perilaku, dan afektif. Ditinjau dari gejala fisik, dapat mengarah pada kondisi kesehatan fisik ibu rumah tangga tersebut seperti merasa pusing secara tiba-tiba ketika sedang melakukan pekerjaan rumah dan dapat dilihat dari kualitas tidur individu. Stres juga dapat dilihat dari segi kognitif individu, misalnya intensitas seorang ibu rumah tangga dalam memikirkan pekerjaan rumah tangga yang harus diselesaikan. Seorang ibu rumah tangga yang terlalu sering memikirkan pekerjaan rumah tangga yang harus diselesaikan, tentu akan membuat ia menjadi tidak nyaman dengan kondisi tersebut. Kondisi yang membuat individu merasa tidak nyaman secara berkelanjutan akan berpotensi menjadi faktor pemicu stres. Individu yang sedang mengalami stres dapat dilihat dari perilaku sehari-hari individu tersebut, seperti agresivitas individu akan cenderung meningkat ketika ia sedang mengalami stres. Hal itu dapat berdampak pada interaksi interpersonal individu tersebut dengan lingkungan sosial di sekitarnya. Menurut Rini (2002) stres bisa berdampak pada interaksi interpersonal, orang yang sedang stres akan lebih sensitif dibandingkan orang yang tidak dalam kondisi stres. Ibu rumah tangga yang merasa tidak nyaman dengan pekerjaan rumah tangga dapat bersikap lebih agresif dan sensitif ketika melakukan pekerjaan rumah. Sikap sensitif tersebut dapat membuat orang lain merasa tidak nyaman yang berpengaruh terhadap sosialisasi individu. Sikap seseorang dapat dipengaruhi oleh emosi dan perasaan yang merupakan ranah dari segi afektif. Individu yang sedang megalami stres 
cenderung tidak dapat menikmati hal yang sedang dilakukan. Seorang ibu rumah tangga yang merasa tidak nyaman dengan pekerjaan rumah tangga akan cenderung tidak dapat menikmati dengan baik hal yang dilakukan tersebut.

Perasaan tidak puas terhadap hal-hal yang dilakukan dapat menuntun seseorang ke dalam ketidakpuasan hidup, sehingga dapat mempengaruhi kualitas hidup individu tersebut. Handoko (2007) menyatakan dalam hasil penelitiannya bahwa sebagian wanita merasa puas dengan profesinya sebagai ibu rumah tangga, sebagian lainnya ( lebih dari $70 \%$ pekerjaan rumah tangga) merasa tidak puas dengan tugas-tugas utama yang dikaitkan dengan profesi tersebut. Kejenuhan dan perasaan lelah baik secara fisik maupun mental dapat menjadi faktor pendukung terjadinya ketidakpuasan ibu rumah tangga terhadap perannya. Kesempatan yang terbatas untuk melakukan sosialisasi di lingkungan sosial dalam jangka waktu yang cukup lama juga dapat menyebabkan timbulnya perasaan jenuh. Stres yang dialami oleh ibu rumah tangga tersebut dapat terjadi karena rutinitasnya dalam melakukan pekerjaan rumah tangga yang cenderung monoton dan sangat berpotensi menimbulkan perasaan jenuh. Hudak (1997) menyatakan bahwa salah satu faktor penyebab kejenuhan yaitu melakukan pekerjaan yang diulang-ulang secara rutin. Rutinitas melakukan pekerjaan rumah tangga yang dikerjakan berulang setiap hari merupakan kewajiban yang harus dijalani sebagai seorang wanita yang sudah berumah tangga, sehingga ibu rumah tangga yang mengalami stres akibat pekerjaan rumah tangga berada dalam posisi antara kewajiban yang harus dilakukan dan kejenuhan yang dirasakan.

Penggunaan jasa pembantu rumah tangga dalam sebuah keluarga dimaksudkan untuk membantu para ibu rumah tangga dalam menyelesaikan pekerjaan rumah tangga sehari-hari. Sebagian besar orang menganggap bahwa keberadaan pembantu rumah tangga dalam menyelesaikan pekerjaan rumah tentu akan sangat membantu para ibu rumah tangga. Sebagian ibu rumah tangga tidak ingin terlalu lelah baik secara fisik maupun mental dalam menyelesaikan pekerjaan rumah sehingga memilih untuk menggaji pembantu rumah tangga untuk membantu mereka. Tetapi sebagian lagi tetap memilih menyelesaikan kewajibannya seorang diri tanpa bantuan jasa pembantu karena berbagai alasan seperti merasa tidak nyaman dengan kehadiran orang lain dalam keluarga, keberatan dalam memberi upah sejumlah ratusan ribu rupiah per bulan, atau merasa tidak puas jika pekerjaan rumah tangga dilakukan oleh orang lain. Ini merupakan pilihan yang dapat dipertimbangkan oleh para ibu rumah tangga. Perlu dilihat kembali kondisi pekerjaan rumah tangga yang harus diselesaikan dalam keluarga tersebut. Jika pekerjaan rumah tangga yang harus diselesaikan begitu banyak sehingga menimbulkan perasaan tidak nyaman pada ibu rumah tangga itu sendiri, maka penggunaan jasa pembantu rumah tangga perlu dipertimbangkan. Hal tersebut diharapkan dapat membantu menekan risiko timbulnya stres pada ibu rumah tangga.

Sebuah penelitian pernah dilakukan di Taiwan oleh Lu (2007) dalam melihat gejala-gejala stres pada ibu rumah tangga. Hasil penelitian tersebut menyatakan bahwa ibu rumah tangga yang berusia muda lebih mudah mengalami gejala stres dibandingkan pada ibu rumah tangga yang berusia lebih tua. Oleh karena itu dalam penelitian ini peneliti mencoba untuk melihat perbedaan tingkat stres pada subjek penelitian ini dengan frekuensi umur yang dimiliki. Hal ini diharapkan dapat memperkaya hasil penelitian ini. Hasil analisis data menunjukkan bahwa tidak ada perbedaan tingkat stres yang signifikan antara subjek pada kategori rentang usia 30-40 tahun dan subjek pada kategori rentang usia 41-55 tahun. Oleh karena itu dapat disimpulkan bahwa tingkat stres ibu rumah tangga yang menggunakan dan tidak menggunakan pembantu rumah tangga pada kategori rentang usia 30-40 tahun dan kategori rentang usia 41-55 tahun dalam penelitian ini tidak mengalami perbedaan yang signifikan. Seorang wanita yang telah berumah tangga secara otomatis akan mengemban beberapa kewajiban terkait dengan perannya sebagai ibu rumah tangga. Dalam melaksanakan kewajiban tidak dapat memandang usia. Baik usia tua maupun muda, harus dapat melaksanakan kewajiban dengan baik terkait dengan tanggung jawabnya sebagai seorang ibu rumah tangga. Kemampuan dalam melaksanakan kewajiban tersebut akan mempengaruhi cara dalam menghadapi berbagai tanggung jawab yang ada. Jika seseorang tidak mampu dalam melaksanakan kewajiban dengan baik maka akan rentan menyebabkan tekanan yang memicu timbulnya stres. Oleh karena itu, tekanan terkait kewajiban dapat menjadi faktor pemicu timbulnya stres yang dapat terjadi pada siapa pun serta dari berbagai kalangan usia baik tua atau pun muda. Salah satu fenomena menarik ialah semakin mudanya usia penderita stres. Jika beberapa tahun yang lalu, stres lebih banyak dialami oleh usia produktif diatas 20 tahun, kini stres banyak diderita oleh anak usia remaja bahkan dalam beberapa kasus anak-anak diperkirakan telah mengalami stres (Pranadji \& Nurlaela, 2009). Oleh sebab itu stres dapat mengancam berbagai kalangan usia mulai dari anak-anak hingga usia tua.

Perbedaan tingkat stres pada kedua kelompok ibu rumah tangga dalam penelitian ini dapat dilihat dengan lebih jelas jika ditinjau dari aspek-aspek yang diukur dalam penelitian ini. Sebagai data tambahan peneliti juga melihat perbedaan tingkat stres pada kedua kelompok ibu rumah tangga dilihat dari keempat aspek dalam skala stres pada ibu rumah tangga yaitu aspek kognitif, afektif, perilaku, dan fisik. Hasil analisa menunjukkan bahwa secara statistik terdapat perbedaan tingkat stres pada kedua kelompok ibu rumah tangga pada masing-masing aspek yang diukur. Berdasarkan beberapa kesimpulan yang telah disebutkan sebelumnya, maka dapat diketahui bahwa kategori stres rendah mendominasi 
dalam keempat aspek pada kelompok ibu rumah tangga yang menggunakan pembantu rumah tangga sedangkan kategori stres sedang mendominasi dalam keempat aspek pada kelompok ibu rumah tangga yang tidak menggunakan pembantu rumah tangga. Oleh karena itu, hal ini semakin memperkuat hasil penelitian ini yang menyatakan bahwa terdapat perbedaan tingkat stres yang signifikan pada ibu rumah tangga yang menggunakan dan tidak menggunakan pembantu rumah tangga dimana hasilnya menyatakan bahwa pada kelompok ibu rumah tangga yang menggunakan pembantu rumah tangga di dominasi oleh kategori stres rendah dan pada kelompok ibu rumah tangga yang tidak menggunakan pembantu rumah tangga di dominasi oleh kategori stres sedang.

Hasil analisa statistik menggambarkan adanya perbedaan tingkat stres yang signifikan pada kedua kelompok ibu rumah tangga di tinjau dari aspek kognitif, aspek afektif, aspek fisik, dan aspek perilaku. Berdasarkan hasil pengkategorian skor stres pada masing-masing aspek, kelompok ibu rumah tangga yang menggunakan pembantu rumah tangga memiliki stres yang lebih rendah dari kelompok ibu rumah tangga yang tidak menggunakan pembantu rumah tangga. Hal ini terjadi pada keempat aspek yang di uji. Hasil tersebut menunjukkan bahwa jika di tinjau dari aspek kognitif, afektif, perilaku, dan fisik, kelompok ibu rumah tangga yang menggunakan pembantu rumah tangga memiliki stres yang lebih rendah dari kelompok ibu rumah tangga yang tidak menggunakan pembantu. Perihal ini sesuai dengan beberapa teori di bawah ini yang menunjukkan bahwa gejala-gejala stres dapat di ukur melalui beberapa aspek diantaranya aspek kognitif, afektif, perilaku, maupun fisik.

Vlisides, Eddy, \& Mozie (1994) mengatakan bahwa pada dasarnya secara umum, gejala stres dapat diidentifikasi ke dalam 4 tipe yang berbeda, yaitu : perilaku, emosi, kognitif dan fisik. Bentuk perilaku pada orang yang mengalami stres contohnya adalah penundaan, kehilangan nafsu makan, menarik diri, emosi yang meledak dan agresi. Pada gejala emosi ditandai dengan kecemasan, ketakutan, cepat marah, depresi, frustasi, perasaan tidak menentu dan kehilangan kontrol, penurunan kepuasan kerja. Pada tipe kognitif dinyatakan bahwa orang yang stres cenderung kehilangan motivasi dan konsentrasi, kesalahan persepsi, kebingungan. Pada gejala fisik ditandai dengan fisik yang lemah, kepala pusing, tegang otot, hipertensi. Oleh karena itu berdasarkan pada beberapa teori tersebut maka gejala-gejala stres secara umum dapat dilihat pada beberapa aspek seperti aspek kognitif, aspek afektif, aspek perilaku, dan aspek fisik sehingga dapat membedakan dengan baik individu yang sedang mengalami dan tidak mengalami stres.

Berdasarkan hasil dan pembahasan, maka dapat disimpulkan bahwa terdapat perbedaan tingkat stres pada ibu rumah tangga yang menggunakan dan tidak menggunakan pembantu rumah tangga. Kelompok ibu rumah tangga yang menggunakan pembantu rumah tangga memiliki tingkat stres rendah, sedangkan kelompok ibu rumah tangga yang tidak menggunakan pembantu rumah tangga memiliki tingkat stres yang sedang. Berdasarkan hasil analisa tambahan pada data penelitian, dinyatakan bahwa tidak terdapat perbedaan tingkat stres yang signifikan pada responden dengan frekuensi umur 30 hingga 40 tahun dan 41 hingga 55 tahun serta tingkat stres subjek pada kelompok ibu rumah tangga yang menggunakan dan tidak menggunakan pembantu rumah tangga memiliki perbedaan jika ditinjau dari aspek kognitif, afektif, perilaku, dan fisik yang merupakan aspek dalam skala stres dalam penelitian ini.

Saran praktis yang dapat peneliti berikan untuk para ibu rumah tangga yang tidak bekerja adalah pentingnya memahami penggunaan jasa pembantu rumah tangga yang ternyata dapat mempengaruhi tingkat stres para ibu rumah tangga terkait dengan pekerjaan rumah sehari-hari. Maka bantuan dari pihak lain seperti pembantu rumah tangga dalam menangani pekerjaan rumah tangga sehari-hari dapat membantu para ibu rumah tangga untuk lebih santai dalam menghadapi pekerjaan rumah tersebut. Para ibu rumah tangga juga diharapkan dapat bersikap realistis terhadap harapan dan kenyataan terkait pekerjaan rumah tangga, agar tidak terlalu ideal dalam mengerjakan seluruh pekerjaan rumah tangga karena kekurangan dalam mengerjakan pekerjaan adalah hal yang wajar. Selain itu agar para ibu rumah tangga dapat menyelingi kesibukan sebagai ibu rumah tangga dengan kegiatan-kegiatan yang positif seperti olahraga atau melakukan hobi yang bermanfaat dan berusaha untuk selalu rileks serta berpikir positif setiap waktu. Oleh karena itu diharapkan dapat menekan risiko timbulnya stres.

Saran bagi peneliti selanjutnya yaitu agar dapat menggunakan teknik sampling yang lebih kompatibel agar data bisa didapatkan dengan mudah dan terdistribusi normal. Selain itu bagi peneliti selanjutnya dapat mempertimbangkan adanya variabel-variabel lain yang dapat mempengaruhi tingkat stres ibu rumah tangga yang tidak bekerja. Untuk mendapatkan data yang lebih mendalam dapat dilakukan dengan metode penelitian yang lain seperti metode kualitatif dengan teknik pengambilan data tambahan berupa wawancara dan observasi untuk memperdalam hasil penelitian dengan tema stres pada ibu rumah tangga. Disarankan untuk peneliti selanjutnya agar dapat membuat atau menemukan alat ukur yang lebih valid dan reliabel sehingga dapat mengukur aspekaspek yang diinginkan dengan baik.

\section{DAFTAR PUSTAKA}

Andriani, H. (2003). Faktor-faktor penyebab stres pada siswa SLTP. Bandung: PPB FIP UPI. 
Anonim (2013, April). MenitsBerita. Retrieved April 2013, from Menits

Berita: http://news.menits.com/post/2748654930/2013/04/07/.html

Astuti, D. (2000). Jejak seribu tangan. Yogyakarta: Yayasan Tjoet Nyak Dien.

Atwater, E. (1983). Psychology of adjustment (2nd edition). New Jersey: Prentice Hall Inc.

Azwar, D. S. (1996). Tes prestasi: fungsi dan pengembangan pengukuran prestasi belajar. Yogyakarta: Pustaka Belajar.

Azwar, S. (2000). Validitas dan reliabilitas. Yogyakarta: Pustaka Belajar.

Blechman, E. A., \& Brownell, K. D. (1998). Behavioral medicine \& women (a comprehensive handbook). New York: The Guilford Press.

Boediono, D., \& Koster, D. I. (2004). Teori dan aplikasi statistika dan probabilitas. Bandung: PT Remaja Rosdakarya.

Dwijayanti, J. E. (1999). Perbedaan motif antara ibu rumah tangga yang bekerja dan yang tidak bekerja dalam mengikuti sekolah pengembangan pribadi dari jhon robert powers. Media Psikologi Indonesia, 14.

Frieze, I. (1978). The women and sex roles: a social psychological perspective. New York: W. W. Norton and Co.

Galbraith, J. K. (1973). The economics of american housewife. Atlantic Monthly.

Handoko, L. S. (2007). Apresiasi ibu rumah tangga di surabaya mengenai penggunaan tembang populer pada iklan di media televisi. Surabaya: Universitas Kristen Petra.

Hariadja, M. T. (2001). Manajemen personalia \& sumberdaya manusia cetakan ke-15. Yogyakarta: BPFE-Yogyakarta.

Higgins, J. E., Kleinbaum, A. P., \& Miller, P. (1985). Design methodology for randomized clinical trials; family health international. North Carolina, USA: Research Triangle Park.

Hudak, C. M., \& Gallo, B. M. (1997). Keperawatan kritis: pendekatan holistik. Jakarta: EGC.

Indriana, Y., Kristiana, I. F., Sonda, A. A., \& Intanirian, A. (2008). Tingkat stres lansia di panti wredha "pucang gading" Semarang. Jurnal Psikologi Undip , 8.

Jacquiline, A. M. (1997). Mengatasi stres di tempat kerja. (S. Lyndon, Ed.) Tangerang: Binarupa Aksara.

Kartono, K. (1992). Psikologi wanita: mengenal wanita sebagai ibu dan nenek. Bandung: Mandar Maju.
Komalasari, K., \& Saripudin, D. (2008). Perlindungan hak-hak pembantu rumah tangga (studi kasus pada yayasan sosial purnakarya kota bandung). Sosiohumanika.

Korchin, S. J. (1976). Modern clinical psychology: principles of intervention in the clinic and community. England: Basic Books.

Kurnianingtyas, R. (2009). Penerimaan diri pada wanita bekerja usia dewasa dini ditinjau dari status pernikahan. Surakarta: Universitas Muhammadiyah.

Kusdiyarti, W. (2007). Pengaruh metode pembelajaran kooperatif tipe team games tournament terhadap prestasi belajar matematika ditinjau dari kemampuan awal siswa. Surakarta: Universitas Muhammadiyah Surakarta.

Lu, L. (2007, September). Life events, social support and depression amongst taiwanese housewives. Counselling Psychology Quarterly.

Maramis, W. F. (1994). Ilmu kedokteran jiwa. Surabaya: Airlangga Press.

Mumtahinnah, N. (2007). Hubungan antara stres dengan agresi pada ibu rumah tangga yang tidak bekerja. Universitas Gunadarma.

Nurgiyantoro, B., Gunawan, \& Marzuki. (2009). Statistik Terapan untuk Penelitian Ilmu-ilmu Sosial. Yogyakarta: Gajah Mada University Press.

Nurhadi, M. (2009). Perubahan peran ibu rumah tangga pengaruhnya terhadap harmonisasi rumah tangga. Jurnal sosiologi DiLeMa , 21.

Nurlaila, A. (2011, Desember). Vivanews.com. Retrieved November 2012, from Vivanews.com: http://www.vivanews.com

Oolaneburger, J. (2002). Sosiologi wanita. Jakarta: PT. Asdi Mahasatya.

Pocock, S. J. (1983). Clinical trials a practical approach. Chichester New York Brisbane Toronto Singapore: John Wiley \& Sons.

Panji, M. (2008, Agustus). Kompas.com. Retrieved November 2012, from Kompas.com: http://health.kompas.com/read/2008/08/06/14345736/Bila.S tres.di.Rumah

Pranadji, D. K., \& Nurlaela. (2009). Faktor-faktor yang mempengaruhi tingkat stres pada anak usia sekolah dasar yang sibuk dan tidak Sibuk. Jurnal Ilmu Keluarga dan Konsumen , 2.

Pranoto, A. D. (2013, Maret). detikSurabaya. Retrieved April 2013, from detikSurabaya: http://surabaya.detik.com/read/2013/03/07/121024/2188372 /475/diduga-stres-ibu-rumah-tangga-loncat-dari-jembatansetinggi-50-meter 
Robbins, S. P. (2006). Perilaku organisasi (alih bahasa drs. benjamin molan), edisi bahasa indonesia. Klaten: PT. INTAN SEJATI.

Rumiani. (2010). Optimalisasi peran keluarga sebagai stres buffer dalam menghadapi bencana. Universitas Islam Indonesia.

Sandimin, L. J. (2009). Representasi ibu rumah tangga dalam serial "desperate housewives". Surabaya: Universitas Kristen Petra.

Sedarmayanti. (1996). Tata kerja dan produktivitas kerja, suatu tinjauan dari aspek ergonomi akan kaitan antara manusia dan lingkungan kerjanya. Bandung: Mandar Maju.

Sheridan, C. L., \& Radmacher, S. A. (1992). Health psychology challenging the biomedical model. New York: John Wiley and Sons Inc.

Siswanti, Y. (2006). Analisis pengaruh stres kerja dalam memediasi hubungan antara politik organisasional dengan perilaku agresif. Jurnal Siasat Bisnis , 11, 165-180.

Sugiyono, P. D. (2005). Metode penelitian administrasi. Bandung: Alfabeta.

Supratiknya, D. A. (2000). Statistik psikologi. Jakarta: Grasindo.

Taylor, S. E. (1995). Health psychology. Los Angeles: McGraw-Hill International Editions

Trihendradi, C. (2005). Step by step SPSS 13: analisis data statistik. Yogyakarta: Andi Yogyakarta.

Tunjungsari, P. (2011). Pengaruh stres kerja terhadap kepuasan kerja karyawan pada kantor pusat pt. pos indonesia (persero) bandung. Bandung: Perpustakaan UNIKOM.

Vlisides, C. E., Eddy, J. P., \& Mozie, D. (1994). Stres and stresors: definition, identification and strategy for higher education constituents. College Student Journal , 28 (1), 122-124.

W. C. Burr, S. R. (1994). Reexamining family stres: new theory and research. California: Sage Publishers, Inc.

Wangi, M. S. (2008). Hubungan kerja pembantu rumah tangga dengan majikan di surakarta. UNISRI, XX. 